\title{
The Quran: Word List
}

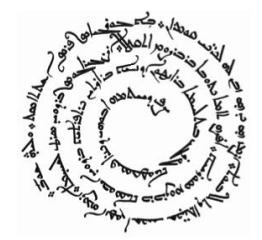




\section{Gorgias Islamic Studies}

14

Gorgias Islamic Studies spans a wide range of subject areas, seeking to understand Islam as a complete cultural and religious unity. This series draws together political, socio-cultural, textual, and historical approaches from across disciplines. Containing monographs, edited collections of essays, and primary source texts in translation, this series seeks to present a comprehensive, critical, and constructive picture of this centuries- and continent-spanning religion. 


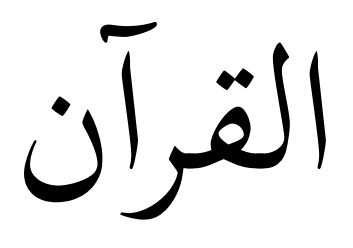

\section{The Quran}

\section{Word List}

Adjectives, Nouns, Proper Nouns and Verbs

Volume 3

Assigned Lemmas and Roots

Elie Wardini

Gorgias

2020 
Gorgias Press LLC, 954 River Road, Piscataway, NJ, 08854, USA

www.gorgiaspress.com

Copyright (C) 2020 by Gorgias Press LLC

All rights reserved under International and Pan-American Copyright Conventions. No part of this publication may be reproduced, stored in a retrieval system or transmitted in any form or by any means, electronic, mechanical, photocopying, recording, scanning or otherwise without the prior written permission of Gorgias Press LLC.

2020

$x$

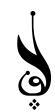

ISBN 978-1-4632-4177-3

Library of Congress Cataloging-in-Publication Data

A Cataloging-in-Publication Record is available from the Library of Congress.

Printed in the United States of America 


\section{The Quran: Word List}

The aim with the present series, The Quran: Word List, is to present the Quran as raw data with as little interpretation as possible.

The digital text used is the Uthmani text of the Tanzil Quran Text (for attribution see the following page). This text is widely used, and we have conducted some comparison to pre-digital age printed editions of the Quran.

In volumes one and two each attested word form in the Quran, in this series adjectives, nouns, proper nouns and verbs, is listed with no parsing and no alteration whatsoever to the orthography of the Tanzil Uthmani text. They are listed as follows: word form $<$ lemma $<$ root. Volume three consists of two sections. In the first section, the lemmas assigned to each attested word form are listed as follows: lemma $<$ root. In the second section, the assigned roots are listed. Each list is sorted alphabetically according to Arabic and UNICODE order.

In assigning each word a root and lemma, Classical dictionaries and Quran commentaries, as well as modern Quran dictionaries have been consulted. Deciding on these is not always obvious, since classical dictionaries and commentaries sometimes either disagree or present divergent variant readings or root and lemma attributions.

No attention has been given to the semantics of each word. Only on rare occasion have similar forms of words been separated in order to avoid morphological confusion.

All vocalized Arabic text is quoted unaltered in any shape or form from the Tanzil Uthmani text. Unvocalized Arabic text and transcriptions are my own. 


\section{Attribution}

Tanzil Quran Text

Copyright (C) 2008-2019 Tanzil Project

License: Creative Commons Attribution 3.0

This copy of the Quran text is carefully produced, highly verified and continuously monitored by a group of specialists in Tanzil Project.

TERMS OF USE:

- Permission is granted to copy and distribute verbatim copies of this text, but CHANGING IT IS NOT ALLOWED.

- This Quran text can be used in any website or application, provided that its source (Tanzil Project) is clearly indicated, and a link is made to tanzil.net to enable users to keep track of changes.

- This copyright notice shall be included in all verbatim copies of the text, and shall be reproduced appropriately in all files derived from or containing substantial portion of this text.

Please check updates at: http://tanzil.net/updates/

Last downloaded from tanzil.net, May 2019.

from: http://tanzil.net/download

The Arabic font used is: Scheherazade

The present author expresses his deepest gratitude to Tanzil.net for producing this digitalized text of the Quran and allowing the free use of a properly attributed copy.

While this volume does not reproduce the text of the Quran as running text, it does reproduce large relevant sections verbatim. None of the quoted texts have been altered in any shape or form.

The text reproduced here is the Uthmani Text, with aya numbers, as provided by tanzil.com. It is our hope that our small effort contributes to further research on the Quran.

Elie Wardini, Stockholm, February 2020 